\title{
Виживаність хворих на рак стравоходу залежно від локалізації первинної пухлини
}

\author{
Національний інститут раку, Київ \\ Одержано: 14.04 .2020 \\ Прийнято до друку: 28.04.2020 \\ DOI: $10.32471 /$ clinicaloncology.2663-466X.37-1.27028
}

\begin{abstract}
Актуальність. Рак стравоходу (РС) посідає 8-ме місце серед найпоширеніших онкологічних захворювань у світі та 6-те місце за смертністю чоловіків від злоякісних новоутворень. Клінічний перебіг захворювання зумовлений швидким розвитком синдрому дисфагії, на тлі якого протягом кількох місяців розвивається кахексія, хворі зазвичай помирають від аліментарного виснаження. На сьогодні майже немає досліджень, що аналізують виживаність хворих залежно від локалізації первинної пухлини. Мета. Дослідити результати виживаності хворих на РС залежно від локалізації первинної пухлини. Матеріали та методи. Зі 1690 пацієнтів зі злоякісними пухлинами стравоходу проаналізована виживаність 1465 хворих на плоскоклітинний РС залежно від локалізації первинної пухлини за розподілом за стадіями ТNМ та клінічними стадіями. Результати. Серед 1690 хворих на злоякісні захворювання стравоходу, які отримували лікування у науково-дослідному відділенні пухлин органів грудної порожнини, понад $90 \%$ становили чоловіки, середній вік яких становив 58,48 року, причому вікові коливання значні - від 20 до 90 років. Серед гістологічних форм істотно переважав плоскоклітинний РС (86,69\%), його частота залежала від локалізації первинної пухлини у стравоході - при ураженні верхніх відділів та середньої частини внутрішньогрудного відділу його відмічали більш ніж у $90 \%$ випадків, а при ураженні нижньої частини внутрішньогрудного та абдомінального відділів - у 76,05\%. Серед інших гістологічних форм переважала аденокарцинома (82,72\%). Саме хворі на плоскоклітинний РС були залучені до подальшого аналізу. Залежно від рівня локалізації первинної пухлини: більше половини становили хворі на рак середніх відділів, а хворих на рак нижніх відділів було більше у 1,5 рази, ніж хворих на рак верхніх відділів. Характерно, що під час аналізу розподілу хворих за стадіями TNM та клінічними стадіями (ВООз) залежно від рівня локалізації первинної пухлини у стравоході, усі групи виявилися тотожними практично за всіма показниками більше половини хворих становили хворі з ІІА клінічною стадією, серед яких у 1,5-2 рази переважала стадія ТЗNOM0 над T2NOMO. Майже третину від усіх хворих становили пацієнти зі стадією III, де значно домінувала стадія T3N1M0. Майже $10 \%$ становили хворі 3 клінічною стадією IV, серед яких переважали пацієнти з місцевопоширеними формами первинного пухлинного процесу. А найрідше відмічали IIB та особливо стадію I РС. Висновки. Після проведеного аналізу виживаності хворих можна сказати, що достовірно краща виживаність була у хворих на плоскоклітинний рак нижніх відділів стравоходу як при початкових стадіях, так і при місцевопоширених процесах, а виживаність хворих на рак верхніх та середніх відділів достовірно не розрізнялася. Але при клінічній стадії IV достовірної різниці у виживаності хворих залежно від локалізації первинної пухлини не спостерігали.
\end{abstract}

Ключові слова: рак стравоходу; рак верхніх відділів стравоходу; рак середньої частки внутрішньогрудного відділу стравоходу; виживаність

\section{ВСТУП}

Лікування раку стравоходу (РС) є однією з найскладніших проблем сучасної світової онкології. Клінічний перебіг захворювання зумовлений швидким розвитком синдрому дисфагії, на тлі якого протягом кількох місяців розвивається кахексія, хворі зазвичай помирають від аліментарного виснаження.

Другою причиною смерті від РС є широке та раннє метастазування: у разі раку шийного та верхньогрудного відділів - у середостіння, клітинні простори шиї, надключичні зони; у разі раку грудного відділу - по ходу лімфатичних просторів підслизової оболонки стравоходу, у лімфатичні вузли середостіння і навколостравохідну клітковину; рак нижнього відділу стравоходу переважно метастазує в лімфатичні вузли верхнього відділу малого сальника [1].

РС посідає 8-ме місце серед найпоширеніших ракових захворювань у світі [2] та 6-те місце за смертністю чоловіків від злоякісних новоутворень. Захворювання характеризується високою географічною залежністю, розбіжність показників захворюваності між окремими країнами $€ 15-20$-кратною - від 1,7-2,2 на 100 тис. випадків у Ізраїлі, Вірменії, Малі та В’єтнамі до 100,0 на 100 тис. населення у Китаї, Ірані, країнах Центральної та Середньої Азії [3]. В Україні, за даними Національного канцер-реєстру, у 2017 р. зареєстровано 1649 випадків РС, загальна захворюваність становила 4,6 на 100 тис. населення [4]. Чоловіки хворіють частіше, ніж жінки, у співвідношенні 5-10:1 (8,6:1 в Україні), пік захворюваності припадає на віковий період 50-60 років, хворі віком понад 70 років становлять 40\% [5].
Лікування хворих на РС має півторавіковий досвід , якщо рахувати від накладання гастростоми хворому на РС у 1949 р. французьким хірургом Седіло [6]. В сучасному лікуванні РС використовують хірургічне втручання, променеву терапію та хіміотерапію. Історично, з початку XX ст. в основному використовувалась променева терапія, а з $1940-х$ років почався стрімкий розвиток хірургічних методів лікування. Хіміотерапія посідала скромне місце, але з 1990-х років в лікуванні РС все ширше використовується радіохіміотерапія, що дозволило істотно покращити безпосередні результати лікування. Треба зазначити, що тільки хірургічне лікування дає можливість лікувати хворого радикально та визнане «золотим стандартом» у терапії резектабельного РС [7].

У структурі захворюваності на РС переважають хворі на рак верхніх відділів стравоходу (РВВС) - шийного та верхньогрудного, за різними даними $-10-15 \%$ [8].

Доведено, що тютюнопаління та вживання алкоголю $\epsilon$ факторами ризику розвитку РВВС. Мутації в алкогольдегідрогеназі, зокрема 1B та ALDH-2 (двох ферментах, що беруть участь в обміні алкоголю) також пов'язані з виникненням неоплазії у верхніх дихальних шляхах та верхніх відділах стравоходу [9-12].

Висока захворюваність на РВВС спостерігається в Ірані, Центральній Азії, Монголії, Північному Китаї та Південній Африці, що пов'язано з нутритивними та екологічними особливостями цих регіонів. Роль сімейного анамнезу ше не доведена [13]. Вплив професійних факторів також важко оцінити 
самостійно, оскільки РВВС часто відмічають у некваліфікованих працівників промисловості та сільського господарства, серед яких багато споживачів тютюну та/або алкоголю. Високий ступінь впливу поліциклічних ароматичних вуглеводнів також пов'язаний з високим ризиком РВВС [14]. Також суперечливими є результати досліджень зв'язку між інфікуванням вірусом папіломи людини та РВВС через високу захворюваність на цей вірус у регіонах, ендемічних для РВВС [15-17].

Важливо зазначити, що при РВВС гістологічно визначається саме плоскоклітинний рак (до 95\%), водночас у разі онкопатології середніх та нижніх відділів стравоходу спостерігається тенденція до підвищення частоти залозистого раку (до 30\%) [8, 18].

Зазвичай хворих на РВВС прийнято лікувати консервативно як на теренах СНД [1], так і у світі - Національною загальною онкологічною мережею (National Comprehensive Cancer Network - NCCN) та Європейським товариством медичної онкології (European Society for Medical Oncology - ESMO) рекомендована самостійна радіохіміотерапія [7, 19]. Треба зазначити, що пухлини верхніх відділів стравоходу представляють найбільші труднощі для хірургічного лікування, зумовлені анатомічними особливостями будови (близькість гортані, трахеї, глотки, крупних судин, глибина залягання) та характером росту пухлини (розповсюдження уздовж стравоходу, проростання в сусідні органи).

Наразі не існує уніфікованих алгоритмів радикального та паліативного лікування хворих на РВВС. Хворим проводять курси дистанційної променевої терапії, де сумарна вогнищева доза може коливатися в межах 40-75 Гр. Хіміотерапію проводять як у монорежимах, так і в різних комбінаціях цитостатиків під час поліхіміотерапії. Немає консенсусу щодо вибору схем поліхіміотерапії при РВВС та шляху введення хіміопрепаратів, а для найбільш ефективної радіохіміотерапії також немає загальноприйнятих рекомендацій та протоколів.

Найскладнішою залишається проблема хірургічного лікування хворих на РВВС. Операції при такій патології вкрай складні, з високим відсотком післяопераційних ускладнень та летальності, навіть порівняно з хірургічним лікуванням раку інших відділів стравоходу. Вони часто призводять до інвалідизації хворого та значно знижують якість життя.

Адекватна резекція при раку шийного відділу стравоходу часто потребує видалення гортані та частини глотки. Складності здебільшого виникають при відновленні пасажу в зв'язку з віддаленістю органів, необхідних для утворення трансплантата [20]. Різноманітні методики реконструкції видаленої частки стравоходу (вільним кишковим трансплантатом, шкірно-м'язовими клаптями) не набули широкого впровадження в клінічній практиці через високу складність техніки виконання.

Необхідно зауважити, що велика кількість хворих на РС, у тому числі на РВВС, на момент встановлення діагнозу має неоперабельний або ускладнений пухлинний процес, дисфагію високого ступеня, норицеві укладення, які загрожують життю хворого.

При РС немає чітких рекомендацій щодо персоніфікації та індивідуалізації лікування. $€$ окремі повідомлення про вплив молекулярно-біологічних предикторів на перебіг та прогноз захворювання, але до впровадження цих методів при РС у повсякденну практику ще далеко, на відміну від інших злоякісних пухлин.

\section{МАТЕРІАЛИ ТА МЕТОДИ}

Дане дослідження базується на ретроспективних даних клінічних спостережень і вивчених та узагальнених результатах лікування 1690 хворих на злоякісні новоутворення стравоходу, які отримували лікування у науково-дослідному відділенні пухлин органів грудної порожнини Національного інституту раку у 1978-2017 рр., відомості про яких містяться в базі Національного канцер-реєстру України.
Жінок було 138 (8,17\%), чоловіків - 1552 (91,83\%); вік 20-90 років, середній вік хворих становив 58,48 року.

Усіх пацієнтів було розподілено за локалізацією процесу у стравоході:

- з ураженням верхніх відділів стравоходу - 291 (17,22\%) хворих;

- середньої частини внутрішньогрудного відділу $877(51,89 \%)$;

- нижньої частини внутрішньогрудного та абдомінального відділу - 522 (30,89\%) пацієнти.

У дослідження включено лише тих хворих, у яких діагноз підтверджено, за гістологічним типом переважали пацієнти з верифікованим плоскоклітинним РС -1465 (86,69\%).

За рівнем ураження стравоходу було діагностовано РВВС у 265 (91,07\%), рак середньої частки внутрішньогрудного відділу стравоходу (РСЧВВС) - 803 (91,56\%), рак нижньої частки внутрішньогрудного та абдомінального відділів стравоходу (РНЧВАВС) - у 397 (76,05\%) хворих.

За висновком комісії з питань етики Національного інституту раку дослідження проведено з дотриманням етичних норм та стандартів щодо досліджень пацієнтів, які існують на сьогодні (протокол від 26.05.2015 р. № 69).

Серед неплоскоклітинних злоякісних пухлин найчастіше - $186(82,72 \%)$ - спостерігали аденокарциному, а найрідше - гігантоклітинну пухлину, злоякісну гемангіоперицитому, веретеноподібний, лімфоепітеліальний та перехідноклітинний рак - усього по $1(0,44 \%)$ випадку.

Поширеність процесу у хворих на плоскоклітинний рак, відповідно до міжнародної класифікації TNM, подана в табл. 1, а розподіл хворих за клінічними стадіями (ВОО3) - у табл. 2.

Отже, більш ніж у половини хворих 809 (55,22\%) відмічали стадію IIA, тобто хворі не мали регіонарних метастазів. Другою за частотою була стадія III - у хворих були регіонарні метастази - 430 (29,35\%) пацієнтів. Стадія IV не була рідкістю, хворі 3 віддаленими метастазами становили 153 пацієнти (10,44\%). Хворих зі стадією I та ІІВ відмічали рідко - 1,43 та 3,55\% відповідно.

Після усебічного обстеження всіх хворих було проліковано у відділенні, де вони отримували спеціальне стандартне лікування з урахуванням стадії хвороби, загального стану, ускладнень основного захворювання та супутніх захворювань.

Проте в даному розділі ми обмежуємося тільки загальними характеристиками хворих і хвороби.

Таблиця 1. Розподіл хворих на плоскоклітинний РС за стадіями ТNM

\begin{tabular}{ccc}
\hline Стадія & \multicolumn{2}{c}{ Кількість хворих } \\
\cline { 2 - 3 } & $\mathbf{n}$ & $\%$ \\
\hline T1N0M0 & 21 & 1,43 \\
T2N0M0 & 299 & 20,41 \\
T3N0M0 & 510 & 34,81 \\
T1N1M0 & 2 & 0,14 \\
T2N1M0 & 50 & 3,41 \\
T3N1M0 & 298 & 20,34 \\
T4N0M0 & 65 & 4,44 \\
T4N1M0 & 67 & 4,57 \\
T1N0M1 & 1 & 0,07 \\
T2N0M1 & 9 & 0,61 \\
T2N1M1 & 13 & 0,89 \\
T3N0M1 & 13 & 0,89 \\
T3N1M1 & 79 & 5,39 \\
T4N0M1 & 9 & 0,61 \\
T4N1M1 & 29 & 1,98 \\
Уcь0r0 & 1465 & 100,00 \\
\hline
\end{tabular}

Таблиця 2. Розподіл хворих на плоскоклітинний РС за клінічними стадіями (В003)

\begin{tabular}{ccc}
\hline \multirow{2}{*}{ Стадія } & \multicolumn{3}{c}{ Кількість хворих } \\
\cline { 2 - 3 } & $\mathbf{n}$ & $\%$ \\
\hline I & 21 & 1,43 \\
IIA & 809 & 55,22 \\
III & 52 & 3,55 \\
IV & 430 & 29,35 \\
Усього & 153 & 10,44 \\
\hline
\end{tabular}


У зв’язку з тим, що в даному дослідженні основна увага приділяється вивченню саме проблеми хворих на РВВС, ми провели поглиблений аналіз розподілу пацієнтів залежно від рівня локалізації первинної пухлини у стравоході за стадіями міжнародної класифікації ТNM та клінічними стадіями (BOO3). Тому розподіл хворих на плоскоклітинний РВВС за означеними критеріями відповідно до міжнародної класифікації TNM та групування за клінічними стадіями (BOO3) наведено в табл. 3. Таким чином, за результатами аналізу, найбільшу частину становили хворі зі стадією IIA - 155 пацієнтів (58,49\% від загальної кількості хворих на РВВС), причому хворі зі стадією Т3N0M0 переважали порівняно з Т2N0M0 95 (35,85\%) порівняно з 60 (22,64\%). Численною виявилася група хворих з клінічною стадією III, тобто з місцевопоширеним процесом - $75(28,30 \%)$ хворих, у якій значно переважали пацієнти зі стадією Т3N1 M0 - 46 (17,36\%). Чималою була кількість хворих з віддаленими метастазами - 28 (10,57\%) хворих, а значно переважали хворі із стадіями Т3-4N1M1 (22 з 28), тобто пацієнти, у яких відмічали, окрім віддалених метастазів, ще й більш поширений первинний процес з регіонарними метастазами. Зі стадіями I та IІВ було всього 7 хворих (відповідно $1,51$ та $1,13 \%)$, таких хворих відмічали дуже рідко.

Відповідний розподіл хворих на плоскоклітинний РСЧВВС, а також РНЧВАВС, наведено в табл. 4 та 5.

При аналізі розподілу хворих на плоскоклітинний РСЧВВС (див. табл. 4) картина є практично ідентичною такій

Таблиця 3. Розподіл хворих на плоскоклітинний РВВС за стадіями TNM та клінічними стадіями (В003)

\begin{tabular}{|c|c|c|c|c|c|c|c|}
\hline \multirow{4}{*}{ Стадія } & \multirow{4}{*}{ TNM } & \multicolumn{6}{|c|}{ Розподіл хворих на плоскоклітинний РВВС } \\
\hline & & \multicolumn{3}{|c|}{ за стадіями TNM } & \multicolumn{3}{|c|}{ за клінічними стадіями (В003) } \\
\hline & & \multirow[b]{2}{*}{$\mathbf{n}$} & \multicolumn{2}{|c|}{ \% від кількості хворих } & \multirow{2}{*}{$\mathbf{n}$} & \multicolumn{2}{|c|}{ \% від кількості хворих } \\
\hline & & & PC & PBBC & & PC & PBBC \\
\hline 1 & T1N0M0 & 4 & 0,27 & 1,51 & 4 & 0,27 & 1,51 \\
\hline \multirow{2}{*}{$\| A$} & T2NOMO & 60 & 4,10 & 22,64 & \multirow{2}{*}{155} & \multirow{2}{*}{10,58} & \multirow{2}{*}{58,49} \\
\hline & T3NOMO & 95 & 6,48 & 35,85 & & & \\
\hline \multirow{3}{*}{ IIB } & T1N1M0 & 0 & 0,00 & 0,00 & \multirow{3}{*}{3} & \multirow{3}{*}{0,20} & \multirow[b]{2}{*}{1,13} \\
\hline & T2N1M0 & 3 & 0,20 & 1,13 & & & \\
\hline & T3N1M0 & 46 & 3,14 & 17,36 & & & \\
\hline \multirow[t]{2}{*}{ III } & T4NOMO & 15 & 1,02 & 5,66 & \multirow[t]{2}{*}{75} & \multirow[t]{2}{*}{5,12} & \multirow[t]{2}{*}{28,30} \\
\hline & T4N1M0 & 14 & 0,96 & 5,28 & & & \\
\hline \multirow{8}{*}{ IV } & T1N0M1 & 0 & 0,00 & 0,00 & \multirow{7}{*}{28} & \multirow{7}{*}{1,91} & \multirow{7}{*}{10,57} \\
\hline & T2N0M1 & 1 & 0,07 & 0,38 & & & \\
\hline & T2N1M1 & 2 & 0,14 & 0,75 & & & \\
\hline & T3N0M1 & 2 & 0,14 & 0,75 & & & \\
\hline & T3N1M1 & 14 & 0,96 & 5,28 & & & \\
\hline & T4N0M1 & 1 & 0,07 & 0,38 & & & \\
\hline & T4N1M1 & 8 & 0,55 & 3,02 & & & \\
\hline & Усього & 265 & 18,09 & 100,00 & 265 & 18,09 & 100,00 \\
\hline
\end{tabular}

Таблиця 4. Розподіл хворих на плоскоклітинний РСЧВВС за стадіями ТNM та групування за клінічними стадіями (В003)

\begin{tabular}{|c|c|c|c|c|c|c|c|}
\hline \multirow{4}{*}{ Стадія } & \multirow{4}{*}{ TNM } & \multicolumn{6}{|c|}{ Розподіл хворих на плоскоклітинний РСЧВВС } \\
\hline & & \multicolumn{3}{|c|}{ за стадіями TNM } & \multicolumn{3}{|c|}{ за клінічними стадіями (В003) } \\
\hline & & \multirow{2}{*}{$\mathbf{n}$} & \multicolumn{2}{|c|}{ \% від кількості хворих } & \multirow{2}{*}{$\mathbf{n}$} & \multicolumn{2}{|c|}{ \% від кількості хворих } \\
\hline & & & PC & PC c/3 & & PC & PC c/3 \\
\hline I & T1NOMO & 10 & 0,68 & 1,25 & 10 & 0,68 & 1,25 \\
\hline \multirow{2}{*}{$\| A$} & T2NOMO & 159 & 10,85 & 19,80 & \multirow{2}{*}{436} & \multirow{2}{*}{29,76} & \multirow{2}{*}{54,30} \\
\hline & T3NOMO & 277 & 18,91 & 34,50 & & & \\
\hline \multirow{3}{*}{ IIB } & T1N1M0 & 0 & 0,00 & 0,00 & \multirow{2}{*}{27} & \multirow{3}{*}{1,84} & \multirow{3}{*}{3,36} \\
\hline & T2N1M0 & 27 & 1,84 & 3,36 & & & \\
\hline & T3N1M0 & 164 & 11,19 & 20,42 & & & \\
\hline \multirow[t]{2}{*}{ III } & T4NOMO & 34 & 2,32 & 4,23 & \multirow[t]{2}{*}{243} & \multirow[t]{2}{*}{16,59} & \multirow[t]{2}{*}{30,26} \\
\hline & T4N1M0 & 45 & 3,07 & 5,60 & & & \\
\hline \multirow{8}{*}{ IV } & T1N0M1 & 0 & 0,00 & 0,00 & \multirow{7}{*}{87} & \multirow{7}{*}{5,94} & \multirow{7}{*}{10,83} \\
\hline & T2NOM1 & 6 & 0,41 & 0,75 & & & \\
\hline & T2N1M1 & 9 & 0,61 & 1,12 & & & \\
\hline & T3N0M1 & 11 & 0,75 & 1,37 & & & \\
\hline & T3N1M1 & 44 & 3,00 & 5,48 & & & \\
\hline & T4NOM1 & 5 & 0,34 & 0,62 & & & \\
\hline & T4N1M1 & 12 & 0,82 & 1,49 & & & \\
\hline & Усього & 803 & 54,81 & 100,00 & 803 & 54,81 & 100,00 \\
\hline
\end{tabular}

Таблиця 5. Розподіл хворих на плоскоклітинний РНЧВАВС за стадіями TNM та групування за клінічними стадіями (В003)

\begin{tabular}{|c|c|c|c|c|c|c|c|}
\hline \multirow{4}{*}{ Стадія } & \multirow{4}{*}{ TNM } & \multicolumn{6}{|c|}{ Розподіл хворих на плоскоклітинний РНЧВАВС } \\
\hline & & \multicolumn{3}{|c|}{ розподіл за стадіями TNM } & \multicolumn{3}{|c|}{ групування за клінічними стадіями (В003) } \\
\hline & & \multirow{2}{*}{$\mathbf{n}$} & \multicolumn{2}{|c|}{ \% від кількості хворих } & \multirow[b]{2}{*}{$\mathbf{n}$} & \multicolumn{2}{|c|}{ \% від кількості хворих } \\
\hline & & & PC & PC H/3 & & PC & $\mathrm{PBBC}$ H/3 \\
\hline $\mathrm{T}$ & T1NOMO & 7 & 0,48 & 1,76 & 7 & 0,48 & 1,76 \\
\hline \multirow[b]{2}{*}{$\| A$} & T2NOMO & 80 & 5,46 & 20,15 & \multirow{2}{*}{218} & \multirow[b]{2}{*}{14,88} & \multirow[b]{2}{*}{54,91} \\
\hline & T3NOMO & 138 & 9,42 & 34,76 & & & \\
\hline \multirow{3}{*}{ IIB } & T1N1M0 & 2 & 0,14 & 0,50 & \multirow{2}{*}{22} & \multirow{2}{*}{1,50} & \multirow{2}{*}{5,54} \\
\hline & T2N1M0 & 20 & 1,37 & 5,04 & & & \\
\hline & T3N1M0 & 88 & 6,01 & 22,17 & & & \\
\hline \multirow[t]{2}{*}{ III } & T4NOMO & 16 & 1,09 & 4,03 & \multirow[t]{2}{*}{112} & \multirow[t]{2}{*}{7,65} & \multirow[t]{2}{*}{28,21} \\
\hline & T4N1M0 & 8 & 0,55 & 2,02 & & & \\
\hline \multirow{8}{*}{ IV } & T1N0M1 & 1 & 0,07 & 0,25 & \multirow{7}{*}{38} & \multirow{7}{*}{2,59} & \multirow{7}{*}{9,57} \\
\hline & T2N0M1 & 2 & 0,14 & 0,50 & & & \\
\hline & T2N1M1 & 2 & 0,14 & 0,50 & & & \\
\hline & T3N0M1 & 0 & 0,00 & 0,00 & & & \\
\hline & T3N1M1 & 21 & 1,43 & 5,29 & & & \\
\hline & T4NOM1 & 3 & 0,20 & 0,76 & & & \\
\hline & T4N1M1 & 9 & 0,61 & 2,27 & & & \\
\hline & & 397 & 27,10 & 100,00 & 397 & 27,10 & 100,00 \\
\hline
\end{tabular}


при розподілі хворих з плоскоклітинним РВВС. Найбільша частка хворих має стадію IIA, що становить більше половини всіх хворих дослідної групи - 436 хворих із 803 (54,30\%) від усіх пацієнтів з РСЧВВС, де домінує кількість хворих з T3N0M0 над T2N0M0 (277 (34,50\%) порівняно з 159 (19,80\%).

Друге місце також посідає група хворих з клінічною стадією III $(243$ (30,26\%) хворих, де більш ніж вдвічі більше хворих зі стадією Т3N1M0 (164 (20,42\%) хворих, ніж разом хворих з T4N0M0 та T4N1M0 (відповідно $45(5,60 \%)$ та $34(4,23 \%)$ хворих). Знову чималою виявилася група хворих з віддаленими метастазами, тобто з клінічною стадією IV - 87 (10,83\%) хворих, де переважали пацієнти з місцевопоширеним первинним процесом T3N0-1M1 та T4N1M1 - 67 із 87 хворих. Найрідше відмічали хворих з клінічними стадіями I та IIB - відповідно $10(1,25 \%)$ та $27(3,36 \%)$.

При аналізі розподілу хворих на плоскоклітинний РНЧВАВС отримані дані корелюють з наведеними при інших локалізаціях первинної пухлини в стравоході - більше половини хворих становили пацієнти з клінічною стадією II218 (54,91\% від усіх хворих на плоскоклітинний РНЧВАВС), з переважанням частки хворих з Т3N0M0 (138 (34,96\%) над T2N0M0 (80 (20,15\%). Друге місце посідає група хворих 3 клінічною стадією III (112 $(28,21 \%)$ хворих із значним переважанням пацієнтів з T3N1M0 (88 $(22,17 \%)$ хворих. Третє місце - хворі з клінічною стадією IV - 38 (9,57\%), де значно домінують пацієнти з місцевопоширеним первинним процесом (T3N1M1 та T4N0-1M1) - 31 з 38 хворих. Стадії II та IIB знову відмічали найрідше - відповідно 7 (1,76\%) та 22 (5,54\%).

Отже, під час аналізу розподілу хворих на плоскоклітинний рак стравоходу за клінічними стадіями та стадіями TNM можна стверджувати наступне. Усі 3 групи пацієнтів були достовірно тотожними за розподілом. Усе нижченаведене стосується як загальної кількості хворих, так і обраних дослідних груп. Більш ніж у половини хворих була IIA клінічна стадія з переважанням частки хворих з T3N0M0 над T2N0M0. Майже у третини всіх хворих відмічали клінічну стадію III, причому значно переважали хворі із стадією T3N1M0. Чималу частку склали хворі з віддаленими метастазами, де, до того ж, переважали пацієнти 3 місцевопоширеними первинними процесами. Хворих з клінічними стадіями I та IIB відмічали значно рідше, ніж інших.

Виходячи з того, що за вказаними критеріями групи були тотожними, їх можна досліджувати.

\section{РЕЗУЛЬТАТИ}

Нам здалося доречним оцінити та проаналізувати загальну виживаність хворих на РС залежно від локалізації первинної пухлини на основі аналізу саме вищенаведених груп хворих, які лікувалися в науково-дослідному відділені пухлин органів грудної порожнини Національного інституту раку.

У табл. 6 узагальнена виживаність хворих залежно від локалізації первинної пухлини.

Також виживаність хворих залежно від локалізації первинної пухлини проілюстровано на рис. 1.

При оцінці розбіжностей виявлено $\chi^{2}=12,04501, \mathrm{p}=0,00243(\mathrm{p}<0,05)$, отже розбіжності достовірні. При порівнянні лонг-рангових критеріїв між окремими групами

Таблиця 6. Виживаність хворих на плоскоклітинний РС залежно від локалізації первинної пухлини,\%

\begin{tabular}{cccc}
\hline $\begin{array}{c}\text { Tривалість спо- } \\
\text { стереження, } \\
\text { років }\end{array}$ & \multicolumn{3}{c}{ Рівень локалізації первинної пухлини } \\
\hline 1 & РВВ, $\mathbf{n = 2 6 5}$ & $\begin{array}{c}\text { PСчВBC, } \\
\mathbf{n = 8 0 3}\end{array}$ & $\begin{array}{c}\text { PHчВАВC, } \\
\mathbf{n}=\mathbf{3 9 7}\end{array}$ \\
\hline 2 & $47,76 \pm 3,12$ & $48,91 \pm 5,79$ & $58,32 \pm 2,52$ \\
3 & $15,47 \pm 2,60$ & $23,68 \pm 4,34$ & $30,89 \pm 2,45$ \\
4 & $13,14 \pm 2,27$ & $13,90 \pm 1,61$ & $21,67 \pm 2,22$ \\
5 & $10,57 \pm 2,16$ & $9,45 \pm 1,78$ & $17,11 \pm 2,06$ \\
6 & $9,79 \pm 2,13$ & $8,37 \pm 0,82$ & $15,36 \pm 1,99$ \\
7 & $8,86 \pm 2,12$ & $7,90 \pm 0,56$ & $13,86 \pm 1,93$ \\
8 & $8,30 \pm 2,13$ & $7,38 \pm 1,70$ & $11,83 \pm 1,85$ \\
9 & $7,03 \pm 2,15$ & $6,02 \pm 1,90$ & $9,08 \pm 1,84$ \\
10 & $5,62 \pm 2,13$ & $4,78 \pm 0,33$ & $7,32 \pm 1,68$ \\
\hline
\end{tabular}

Виживаність хворих на плоскоклітинний рак страховоду (Каплан-Мейер)

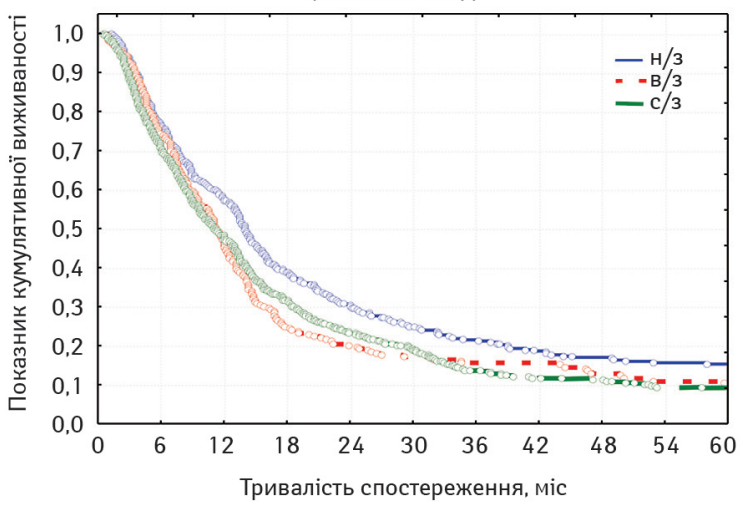

Рис. 1. Виживаність хворих на плоскоклітинний рак стравоходу залежно від локалізації первинної пухлини за методом Каплана - Мейєра: н/3 - хворі на РНЧВАВС; в/3 - хворі на РВВС, с/3 - хворі на РСЧВВС

Таблиця 7. Медіана та середня тривалість життя хворих на PC залежно від локалізації первинної пухлини

\begin{tabular}{lcc}
\hline $\begin{array}{l}\text { Рівень локалізації } \\
\text { первинної пухлини }\end{array}$ & Медіана життя (міс.) & $\begin{array}{c}\text { Середня тривалість } \\
\text { життя (міс.) }\end{array}$ \\
\hline РВBC & 10,62 & 19,15 \\
РСЧВВC & 9,90 & 18,51 \\
РНЧВАВC & 13,02 & 25,00 \\
Разом & 10,62 & 20,39 \\
\hline
\end{tabular}

можна стверджувати, що виживаність Хворих на РНЧВАВС була достовірно кращою, ніж хворих на РВВС ( $\mathrm{p}=0,01326$, тобто $\mathrm{p}<0,05)$ та РСЧВВС $(\mathrm{p}=0,00057 ; \mathrm{p}<0,05)$. Але при порівнянні виживаності хворих на РВВС та РСЧВВС статистичні розбіжності недостовірні ( $\mathrm{p}=0,87895 ; \mathrm{p}>0,05)$. Відповідно, на основі отриманих даних можна стверджувати, що достовірно кращою $€$ виживаність у хворих на РНЧВАВС, ніж при інших локалізаціях первинної пухлини у стравоході. Це підтверджує вивчення медіани та середньої тривалості життя (табл. 7).

Виходячи з отриманих даних, закономірно випливає необхідність більш детального аналізу виживаності хворих не тільки залежно від локалізації пухлини, але й залежно від поширеності процесу. При формуванні груп дослідження ми виходили з питомої ваги різних груп хворих залежно від клінічної стадії (ВОО3) та відповідних факторів, що можна об’єднати при подальшому досліджені.

Отже, першу групу склали хворі зі стадією I-IIA, тобто пацієнти, у яких не виявлено регіонарних метастазів. Хворих зі стадією I було мало - 21 (1,43\% від загальної кількості хворих), тобто для статистичного аналізу така кількість хворих $є$ малоінформативною. Однак кількість хворих зі стадією IIA була найбільшою - 809 (55,22\% від загальної кількості хворих).

Другу групу склали хворі зі стадіями IIB та III, тобто пацієнти з місцевопоширеним процесом - регіонарні метастази або проростання первинної пухлини в суміжні органи та тканини. Знову ж таки, зі стадією IIB було лише 52 хворих (3,55\% від загальної кількості) порівняно з 430 (29,35\% від загальної кількості хворих).

Третю групу склали хворі, які мали клінічну стадію IV, тобто пацієнти з віддаленими метастазами, незалежно від рівня розповсюдження первинної пухлини. Питома вага цієї групи у дослідженні є значною - 153 пацієнти (10,44\% від загальної кількості хворих).

Нижче наведений аналіз виживаності хворих на плоскоклітинний РС стадій I-IIA залежно від локалізації первинної пухлини (табл. 8, рис. 2).

При оцінці розбіжностей виявлено: $\chi^{2}=9,436341$; $\mathrm{p}=0,00894(\mathrm{p}<0,05)$, отже розбіжності достовірні. При порівнянні лонг-рангових критеріїв між окремими групами також, як при вищенаведеному аналізі загальної виживаності, можна 
Таблиця 8. Виживаність хворих на плоскоклітинний РС 1-2А клінічних стадій (В003) залежно від локалізації первинної пухлини,\%

\begin{tabular}{cccc}
\hline Tривалість спо- & \multicolumn{3}{c}{ Рівень локалізації первинної пухлини } \\
\cline { 2 - 4 } стереження, & Рввс & РСчввС & РнчвАВС \\
\hline 1 & $54,34 \pm 3,99$ & $56,96 \pm 2,38$ & $66,13 \pm 3,22$ \\
2 & $22,14 \pm 3,38$ & $29,77 \pm 2,24$ & $38,07 \pm 3,40$ \\
3 & $16,69 \pm 3,05$ & $19,01 \pm 1,96$ & $29,27 \pm 3,21$ \\
4 & $13,06 \pm 2,79$ & $16,67 \pm 1,89$ & $23,74 \pm 3,04$ \\
5 & $9,80 \pm 2,52$ & $13,40 \pm 1,78$ & $21,40 \pm 2,96$ \\
6 & $9,31 \pm 2,49$ & $12,69 \pm 1,75$ & $19,51 \pm 2,89$ \\
7 & $8,21 \pm 2,43$ & $11,91 \pm 1,73$ & $16,03 \pm 2,76$ \\
8 & $7,53 \pm 2,41$ & $11,04 \pm 1,71$ & $15,64 \pm 2,75$ \\
9 & $6,77 \pm 2,39$ & $8,74 \pm 1,63$ & $13,80 \pm 2,72$ \\
10 & $5,42 \pm 2,26$ & $6,62 \pm 1,54$ & $11,67 \pm 2,68$ \\
\hline
\end{tabular}

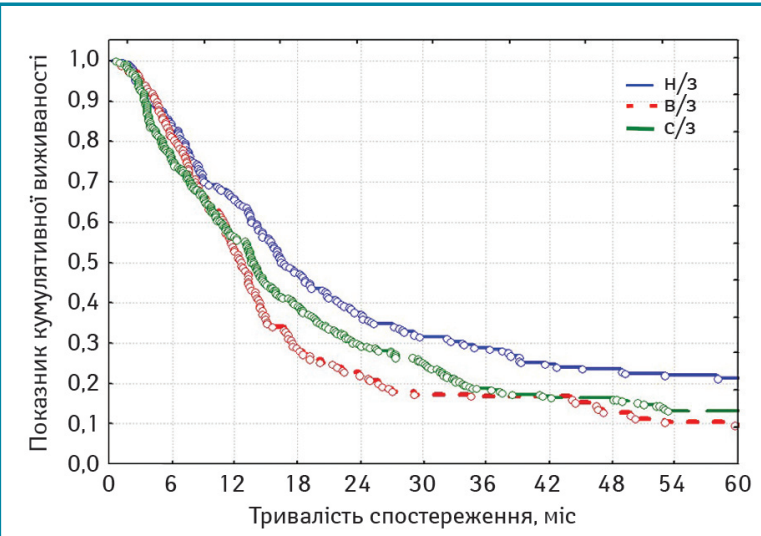

Рис. 2. Виживаність хворих на плоскоклітинний РС I-ІІА клінічних стадій (ВОО3) залежно від локалізації первинної пухлини за методом Каплана - Мейєра: н/3 - хворі на РНЧВАВС; в/3 - хворі на РВВС, с/3 - хворі на РСЧВВС

стверджувати, що виживаність хворих на РНЧВАВС стадій IIIА була достовірно кращою, ніж у хворих на $\mathrm{PBBC} \mathrm{(} \mathrm{p}=0,00280$, тобто $\mathrm{p}<0,05)$ та РСЧВВС ( $\mathrm{p}=0,00640 ; \mathrm{p}<0,05)$. Але при порівнянні виживаності хворих на РВВС та РСЧВВС стадій I-IIA статистичні розбіжності недостовірні ( $\mathrm{p}=0,32320 ; \mathrm{p}>0,05)$. Відповідно, на основі отриманих даних можна стверджувати, що достовірно кращою є виживаність у хворих на РНЧВАВС стадій I-IIA. Це також підтверджує вивчення медіани та середньої тривалості життя (табл. 9).

Нижче наведено аналіз виживаності хворих на плоскоклітинний РС стадій IIB-III залежно від локалізації первинної пухлини (табл. 10, рис. 3).

Таблиця 9. Медіана та середня тривалість життя у хворих на PC 1-2A клінічних стадій (ВО03) залежно від локалізації первинної пухлини

\begin{tabular}{lcc}
\hline $\begin{array}{c}\text { Рівень локалізації } \\
\text { первинної пухлини }\end{array}$ & Медіана життя, міс & $\begin{array}{c}\text { Середня тривалість } \\
\text { життя, міс }\end{array}$ \\
\hline РВВС & 12,00 & 23,11 \\
РСЧВВС & 13,15 & 23,64 \\
РНЧВАВС & 15,44 & 31,07 \\
Разом & 13,26 & 25,56 \\
\hline
\end{tabular}

Таблиця 10. Виживаність хворих на плоскоклітинний РС 2B-3 клінічних стадій (ВО03) залежно від локалізації первинної пухлини, \%

\begin{tabular}{cccc}
\hline $\begin{array}{c}\text { Tривалість спо-- } \\
\text { стереження, } \\
\text { років }\end{array}$ & РВвС & РсчввС & РнчвАВС \\
\hline 1 & $41,89 \pm 5,74$ & $43,52 \pm 3,08$ & $57,36 \pm 4,35$ \\
2 & $18,89 \pm 4,87$ & $19,10 \pm 2,57$ & $26,48 \pm 4,08$ \\
3 & $14,69 \pm 4,61$ & $8,81 \pm 1,93$ & $14,26 \pm 3,39$ \\
4 & $13,22 \pm 4,59$ & $5,17 \pm 1,61$ & $10,03 \pm 2,97$ \\
5 & $11,34 \pm 4,65$ & $4,31 \pm 1,55$ & $8,85 \pm 2,85$ \\
6 & $6,80 \pm 4,48$ & $2,58 \pm 1,33$ & $7,59 \pm 2,71$ \\
7 & $3,40 \pm 4,07$ & $2,15 \pm 1,24$ & $6,96 \pm 2,63$ \\
8 & $1,70 \pm 2,65$ & $1,79 \pm 1,13$ & $6,38 \pm 2,53$ \\
9 & $1,70 \pm 2,65$ & $1,49 \pm 1,02$ & $3,19 \pm 1,82$ \\
10 & $1,70 \pm 2,65$ & $1,25 \pm 0,91$ & $1,91 \pm 1,47$ \\
\hline
\end{tabular}

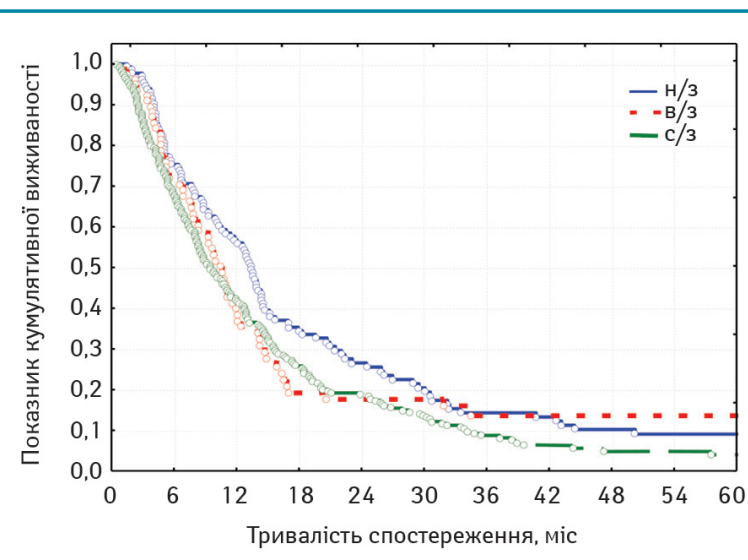

Рис. 3. Виживаність хворих на плоскоклітинний рак стравоходу IB-III клінічних стадій (ВООЗ) залежно від локалізації первинної пухлини за методом Каплана - Мейєра: н/3 - хворі на РНЧВАВС; в/3 - хворі на РВВС, с /3 - хворі на РСЧВВС

Під час оцінки розбіжностей виявлено: $\chi^{2}=7,950987$; $\mathrm{p}=0,01878(\mathrm{p}<0,05)$, отже розбіжності достовірні. При порівнянні лонг-рангових критеріїв між окремими групами, так само як при вищенаведеному аналізі загальної виживаності, можна стверджувати, що виживаність хворих на РНЧВАВС стадій IIB-III була недостовірно кращою, ніж у хворих на PBBC ( $p=0,24475$, тобто $p>0,05)$, але достовірно кращою, ніж у хворих на РСЧВВС ( $p=0,01107 ; \mathrm{p}<0,05)$. Однак при порівнянні виживаності хворих на РВВС та РСЧВВС стадій IIB-III статистичні розбіжності $є$ недостовірними ( $\mathrm{p}=0,43098 ; \mathrm{p}>0,05)$.

Відповідно, на основі отриманих даних можна стверджувати, що достовірно кращою є виживаність у хворих на РНЧВАВС стадій IIB-III, ніж у хворих на РСЧВВС стадій IIB-III. Це також підтверджує вивчення медіани та середньої тривалості життя (табл. 11).

Нижче наведено аналіз виживаності хворих на плоскоклітинний РС з клінічною стадією хвороби IV, тобто тих пацієнтів, у яких виявили віддалені метастази (табл. 12). Надана лише 5-річна виживаність, враховуючи несприятливість цієї стадії хвороби та відсутність віддалених результатів більше 5 років, незалежно від рівня локалізації пухлини у стравоході.

Таблиця 11. Медіана та середня тривалість життя у хворих на РС 2B-3 клінічних стадій (В003) залежно від локалізації первинної пухлини

\begin{tabular}{lcc}
\hline $\begin{array}{c}\text { Рівень локалізації } \\
\text { первинної пухлини }\end{array}$ & Медіана життя, міс & $\begin{array}{c}\text { Середня тривалість } \\
\text { життя, міс }\end{array}$ \\
\hline РВВС & 9,49 & 13,89 \\
РСЧВВС & 8,44 & 13,55 \\
РНЧВАВС & 12,66 & 20,07 \\
Разом & 9,43 & 15,42 \\
\hline
\end{tabular}

Таблиця 12. Виживаність хворих на плоскоклітинний $\mathrm{PC} з$ клінічною стадією 4 (В003)

\begin{tabular}{cc}
\hline Тривалість спостереження, років & Виживаність, $\%$ \\
\hline 1 & $22,30 \pm 3,42$ \\
2 & $6,61 \pm 2,21$ \\
3 & $3,30 \pm 1,74$ \\
4 & $2,20 \pm 1,72$ \\
5 & $1,10 \pm 1,40$ \\
\hline
\end{tabular}

Таблиця 13. Медіана та середня тривалість життя у хворих на РС клінічної стадії 4 (В003) залежно від локалізації первинної пухлини

\begin{tabular}{lcc}
\hline $\begin{array}{c}\text { Рівень локалізації } \\
\text { первинної пухлини }\end{array}$ & Медіана життя, міс & $\begin{array}{c}\text { Середня тривалість } \\
\text { життя, міс }\end{array}$ \\
\hline РВВC & 4,46 & 11,33 \\
РСЧВВC & 5,97 & 7,61 \\
РНЧВАВC & 4,74 & 6,47 \\
Разом & 5,31 & 8,01 \\
\hline
\end{tabular}




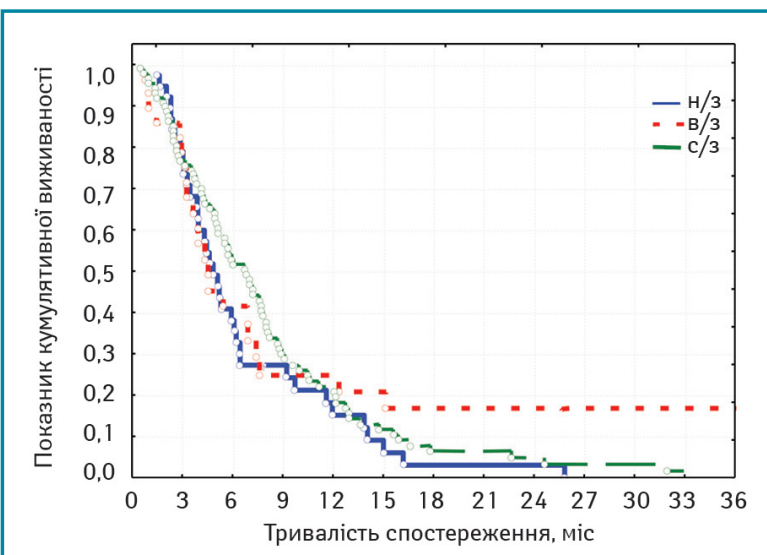

Рис. 4. Виживаність хворих на плоскоклітинний РС з клінічною стадією IV (ВООЗ) залежно від локалізації первинної пухлини за методом Каплана - Мейєра: н/3 - хворі на РНЧВАВС; в/3 - хворі на РВВС, с $/ 3$ - хворі на РСЧВВС

Ми проаналізували виживаність хворих з клінічною стадією IV з урахуванням проявів хвороби (рис. 4).

При оцінці розбіжностей виявлено: $\chi^{2}=1,329521$; $\mathrm{p}=0,51440(\mathrm{p}>0,05)$, отже розбіжності недостовірні. Під час порівняння лонг-рангових критеріїв між окремими групами виявлено, що виживаність хворих стадії IV достовірно не залежала від рівня локалізації пухлини (значення р дорівнювали 0,$26298 ; 0,28882 ; 0,68250$, тобто, усі p >0,05), що свідчить про вирішальне значення рівня занедбаності процесу.

Медіана та середня тривалість життя (табл. 13) при стадіі IV були значно меншими, ніж при інших стадіях.

\section{ВИСНОВКИ.}

Таким чином, узагальнюючи все вищенаведене, маємо можливість виокремити наступні закономірності та тенденції.

1. Серед 1690 хворих на злоякісні захворювання стравоходу, які отримували лікування в науково-дослідному відділенні пухлин органів грудної порожнини, понад $90 \%$ становили чоловіки із середнім віком 58,48 року, причому вікові коливання значні - 20-90 років.

2. Серед гістологічних форм істотно переважав плоскоклітинний РС $(86,69 \%)$, причому його частота залежала від локалізації первинної пухлини в стравоході - при ураженні верхніх відділів та середньої частини внутрішньогрудного відділу його відмічали більш ніж у 90\% випадків, а при ураженні нижньої частини внутрішньогрудного та абдомінального відділів - у 76,05\%.

3. Серед інших гістологічних форм переважала аденокарцинома (82,72\%).

4. Саме хворі на плоскоклітинний РС були залучені до подальшого аналізу. Залежно від рівня локалізації первинної пухлини: більше половини склали хворі на РСЧВВС, а хворих на РНЧВАВС було більше у 1,5 раза, ніж хворих на РВВС. Характерно, що при аналізі розподілу хворих за стадіями ТNM та клінічними стадіями (ВОO3) залежно від рівня локалізації первинної пухлини у стравоході, усі групи виявилися тотожними практично за всіма показниками - більше половини пацієнтів становили хворі з клінічною стадією IIA, серед яких у 1,5-2 рази переважала стадія T3N0M0 над T2N0M0.

5. Майже третину від усіх хворих становили пацієнти зі стадією III, де значно домінувала стадія Т3N1M0. Майже 10\%хворі з клінічною стадією IV, серед яких переважали пацієнти 3 місцевопоширеними формами первинного пухлинного процесу. А найрідше відмічали стадії РС IIB та, особливо, I.

6. Після проведеного аналізу виживаності хворих можна сказати, що достовірно кращою виживаність була у пацієнтів з плоскоклітинним РНЧВАВС, як при початкових стадіях, так і при місцевопоширених процесах, а виживаність хворих на РВВС та РСЧВВС достовірно не розрізнялася. Але, при клінічній стадії IV достовірної різниці у виживаності хворих залежно від локалізації первинної пухлини не спостерігали.

\section{СПИСОК ВИКОРИСТАНОЇ ЛІТЕРАТУРИ}

1. Ганул, В. Л., \& Киркилевский, С. И. (2003). Рак пищевода: руководство для онкологов и хирургов. Киев: Книга Плюс.

2. Domper Arnal, M. J., Ferrandez, Arenas A., Lanas Arbeloa, A. (2015). Esophageal cancer: Risk factors, screening and endoscopic treatment in Western and Eastern countries. World Journal of Gastroenterology, 21(26), 7933-7943. doi: $10.3748 /$ wjg.v21.i26.7933.

3. Jemal, A., Bray, F., Center, M. M., Ferlay, J., Ward, E., Forman, D. (2011). Global cancer statistics. CA: A Cancer Journal for Clinicians, 61(2), 69-90. doi: $10.3322 /$ caac. 20107 .

4. Федоренко, З. П., Гулак, Л. О., Михайлович, Ю. Й., Горох, Є. Л., Рижов, А. Ю., Сумкіна, О. В., \& Куценко, Л. Б. (2020). Рак в Україні, 2018-2019. Захворюваність, смертність, показники діяльності онкологічної служби/гол. ред. О.О. Колеснік. Бюлетень Національного канцер-реєстру України, 20, 101.

5. Янкин, А. В. (2003). Рак пищевода: от статистики к диагностике. Практическая онкология, 4(2), 61-65.

6. Юдин, С. С. (1995). Этюды желудочной хирургии. Москва: Медгиз.

7. Ajani, J. A., D'Amico, T. A., Almhanna, K., Chao, J., Corvera, C., Das, P., Pluchino, L. A. (2015). Esophageal and esophagogastric junction cancers, version 1.2015. Journal of the National Comprehensive Cancer Network, 13(2), 194-227. doi: 10.6004/jnccn.2019.0033

8. Lee, D. J., Harris, A., Gillette, A., Munoz, L, \& Kashima, H. (1984). Carcinoma of the cervical esophagus: diagnosis, management, and results. Southern Medical Journal, 77(11), 1365-1367. doi: 10.1097/00007611-198411000-00004.

9. Morita, M., Saeki, H., Mori, M., Kuwano, H., \& Sugimachi, K. (2002). Risk factors for esophageal cancer and the multiple occurrence of carcinoma in the upper aerodigestive tract. Surgery, 131(1), 1-6. doi.org/10.1067/msy.2002.119287.

10. Pandeya, N., Williams, G., Green, A. C., Webb, P. M., \& Whiteman, D. C. (2009). Australian Cancer Study. Alcohol consumption and the risks of adenocarcinoma and squamous cell carcinoma of the esophagus. Gastroenterology, 136(4), 1215-1224. doi: 10.1053/j.gastro.2008.12.052.

11. Popescu, B., Popescu, C. R., Grigore, R. Mogoantă, C. A., Ioniţă, E., Moculescu, C., \& Berteșteanu, S..V. (2012). Morphology and morphopathology of hypopharyngoesophageal cancer. Romanian Journal of Morphology and Embryology, 53(2), 243-248.

12. Popescu, C. R., Bertesteanu, S. V., Mirea, D., Grigore, R., Ionescu, D., \& Popescu B. (2010). The epidemiology of hypopharynx and cervical esophagus cancer. Journal of Medicine and Life, 3(4), 396-401.

13. Morita, M., Kuwano, H., Nakashima, T., Taketomi, A., Baba, H., Saito, T., ... Sugimachi, K. (1998) Family aggregation of carcinoma of the hypopharynx and cervical esophagus: special reference to multiplicity of cancer in upper aerodigestive tract. International Journal of Cancer, 76(4), 468-471. doi.org/10.1002/(SICI)1097-0215(19980518)76:4<468::AID-IJC4>3.0.CO;2-P.

14. van Gijssel, H. E., Schild, L. J., Watt, D. L. Roth, M. J., Wang, G. Q., Dawsey, S. M.,...P Poirier, M. C. (2004). Polycyclic aromatic hydrocarbon-DNA adducts determined by semiquantitative immunohistochemistry in human esophageal biopsies taken in 1985 . Mutation Research, 547(1-2),55-62. doi: 10.1016/j.mrfmmm.2003.11.010.

15. Guo, F., Liu, Y., Wang, X., Weiss, N. S., Madeleine, M. M., Liu, F., ... Ke, Y. (2012). Human papillomavirus infection and esophageal squamous cell carcinoma: a case-control study. Cancer Epidemiology, Biomarkers \& Prevention, 21(5), 780-785. doi: 10.1158/1055-9965.EPI-11-1206.

16. Ludmir, E. B., Palta, M., Zhang, X. Wu, Y., Willett, C. G., \& Czito, B.G. (2014). Incidence and prognostic impact of high-risk HPV tumor infection in cervical esophageal carcinoma. Journal of Gastrointestinal Oncology, 5(6), 401-407. doi: 10.3978/j.issn.2078-6891.2014.053.

17. Syrjanen, K. J. (2002). HPV infections and oesophageal cancer. Journal of Clinical Pathology, 55(10), 721-728. doi: 10.1136/jcp.55.10.721.

18. Brown, L. M., Devesa, S. S., \& Chow, W. H. (2008). Incidence of adenocarcinoma of the esophagus among white Americans by sex, stage, and age. Journal of the National Cancer Institute, 100 (16),1184-1187. doi: 10.1093/jnci/djn211.

19. Muro, K., Lordick, F., Tsushima, T., Pentheroudakis, G., Baba, E., Lu, Z., Douillard, J.-Y. (2019). Pan-Asian adapted ESMO Clinical Practice Guidelines for the management of patients with metastatic oesophageal cancer: a JSMO-ESMO initiative endorsed by CSCO, KSMO, MOS, SSO and TOS. Annals of Oncology, 30(1), 34-43. doi:https://doi.org/10.1093/annonc/mdy498.

20. Полинкевич, Б. С., Белянский, Л. С., Пустовит, А. А., \& Калашников, А. А. (2011). Опыт лечения рака шейного отдела пищевода. Харківськахірургічна школа, $47(2), 25-27$

\section{Выживаемость больных раком пищевода в зависимости от локализации первичной опухоли}

С.И. Киркилевский, П.С. Крахмалев, Ю.Н. Кондрацкий, Р.И. Фридель

Национальный институт рака, Киев

Резюме. Актуальность. Рак пищевода (РП) занимает 8-е место среди наиболее распространенных онкологических заболеваний в мире и 6-е место - по смертности мужчин вследствие злокачественных новообразований. Клиническое течение заболевания обусловлено быстрым развитием синдрома дисфагии, на фоне которого в течение нескольких месяцев развивается кахексия, больные обычно умирают от алиментарного истощения. На сегодня почти нет исследований, в которых анализировали выживаемость больных в зависимости от локализации первичной опухоли. Цель. Исследовать результаты выживаемости больных РП в зави- 
симости от локализации первичной опухоли. Материалы и методы. Из 1690 пациентов со злокачественными опухолями пищевода проанализирована выживаемость 1465 больных плоскоклеточным РП в зависимости от локализации первичной опухоли по распределению по стадиям ТNM и клиническим стадиям. Результаты. Среди 1690 больных злокачественными заболеваниями пищевода, получавших лечение в научно-исследовательском отделении опухолей органов грудной полости, более $90 \%$ составляли мужчины, средний возраст которых - 58,48 года, причем возрастные колебания значительны - от 20 до 90 лет. Среди гистологических форм существенно преобладал плоскоклеточный РП (86,69\%), его частота зависела от локализации первичной опухоли в пишеводе - при поражении верхних отделов и средней части внутригрудного отдела его отмечали более чем в $90 \%$ случаев, а при поражении нижней части внутригрудного и абдоминального отделов - в 76,05\%. Среди других гистологических форм преобладала аденокарцинома (82,72\%). Именно больные плоскоклеточный РП были привлечены к дальнейшему анализу. В зависимости от уровня локализации первичной опухоли: более половины составляли больные раком средних отделов, а больных раком нижних отделов было больше в 1,5 раза, чем больных раком верхних отделов. Характерно, что при анализе распределения больных по стадиям TNM и клиническими стадиями (BО3) в зависимости от уровня локализации первичной опухоли в пищеводе, все группы оказались тождественными практически по всем показателям - больше половины больных составляли больные с IIA клинической стадией, среди которых в 1,5-2 раза преобладала стадия T3N0M0 над T2N0M0. Почти треть всех больных составляли пациенты со стадией III, где значительно доминировала стадия Т3N1M0. Почти $10 \%$ составляли больные с клинической стадией IV, среди которых преобладали больные с местнораспространенными формами первичного опухолевого процесса. А реже всего отмечали IIВ и, особенно, стадию I РС. Выводы. После проведенного анализа выживаемости больных можно сказать, что достоверно лучше выживаемость была у пациентов с плоскоклеточным раком нижних отделов пищевода как при начальных стадиях, так и при местнораспространенных процессах, а выживаемость больных раком верхних и средних отделов достоверно не различалась. Но при клинической стадии $\mathrm{IV}$ достоверной разницы в выживаемости больных в зависимости от локализации первичной опухоли не наблюдали.

Ключевые слова: рак пищевода; рак верхних отделов пищевода; рак средней доли внутригрудного отдела пищевода; выживаемость.

\section{Survival of patients with esophageal cancer depending on the location of the primary tumor \\ S.I. Kirkilevsky, P.S. Krahmalyov, U.N. Kondratsky, R.I. Frydel} National Cancer Institute, Kyiv

Summary. Relevance. Esophageal cancer (EC) is ranked eighth among the most common cancers in the world and sixth in male deaths from malignancies. The clinical course of the disease is caused by the rapid development of dysphagia syndrome, against

which cachexia develops over several months, patients usually die from alimentary exhaustion. To date, there are almost no studies analyzing the survival of patients depending on the location of the primary tumor. Objective. Assessing the survival results of patients with EC depending on the location of the primary tumor. Materials and methods. Of the 1690 patients who had malignant esophageal tumors, the survival rate of 1465 patients with squamous cell esophageal cancer was analyzed, depending on the location of the primary tumor by TNM distribution and clinical stages. Results. Among 1690 patients with esophageal malignancies receiving treatment in the research department of tumors of the chest cavity, more than $90 \%$ were men with an average age of $58 ? 48$ years, with age fluctuations ranging from 20 to 90 years. Among the histological forms, the squamous cellular EC $(86.69 \%)$ was predominant, and its frequency depended on the level of localization of the primary tumor in the esophagus - with lesions of the upper divisions and middle part of the intrathoracic department, it occurred in more than $90 \%$ of cases, and in lesions of the inferior intrathoracic and abdominal wards - at 76,05\%. Among other histological forms, adenocarcinoma $(82,72 \%)$ prevailed. It was the patients with squamous cell EC who were enrolled for further analysis. Depending on the level of primary tumor localization: more than half were middle-division cancer patients, and lower-division cancer patients were 1,5 times more likely than upper-division cancer patients. It is noteworthy that in the analysis of the distribution of patients by TNM and clinical stages, depending on the level of localization of the primary tumor in the esophagus, all groups were identical in almost all indicators - more than half of patients were patients with IIA clinical stage, among which 1,5-2 times the T3N0M0 stage prevailed over the T2N0M0. Almost a third of all patients were patients with stage III, which was significantly dominated by stage T3N1M0. Almost $10 \%$ were patients with IV clinical stages, among which patients with locally common forms of the primary tumor process predominated. And the least common were IIB and especially I stage EC. Conclusion. After the analysis of the survival of patients, it can be said that the significantly better survival was in patients with squamous cell carcinoma of the lower esophagus both in the initial stages and in locally advanced processes, and the survival of patients with upper and middle divisions was not significantly different. However, no significant difference in patient survival was observed at IV clinical stages depending on the location of the primary tumor.

Key words: esophageal cancer; cancer of the upper esophagus; cancer of the middle lobe of the intrathoracic esophagus; survival

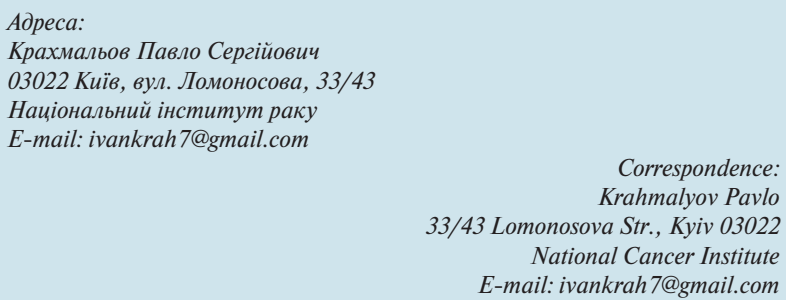

